\title{
ALKYL AND ACYL DERIVATIVES OF TUBERCIDIN
}

\author{
Paul F. Wiley, Jian H. Johnson and Arthur R. Hanze*
}

Research Laboratories, The Upjohn Company

Kalamazoo, Michigan 49001, U.S.A.

(Received for publication April 10, 1976)

\begin{abstract}
A series of acyl and $\mathrm{N}$-alkyl derivatives of tubercidin has been prepared. In vitro and in vivo activities are reported.
\end{abstract}

For many years the antibiotic tubercidin (1) ${ }^{1)}$ has been of interest as an antitumor agent. A large number of tubercidin derivatives and analogs ${ }^{2 \sim 7)}$ have been prepared in order to study structure-activity relationships and in efforts to find compounds having the antitumor activity of tubercidin but being more readily absorbed orally or more effective

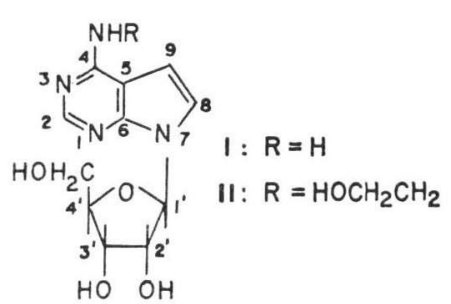
in passing through cell walls. The present paper extends this series and reports the synthesis of a group of compounds derived by esterification of the hydroxyl groups, primarily the $5^{\prime}$ hydroxyl, of tubercidin as well as same $\mathrm{N}$-acylated and $\mathrm{N}$-alkylated derivatives. The purpose of the investigation was to prepare compounds which, while not necessarily antitumor agents in themselves, would be more readily absorbable orally or might pass cell walls more readily and eventually be metabolized in vivo to tubercidin.

\section{Chemistry}

A series of three 5'-O-monoesters of tubercidin (5a, 5b and $\mathbf{5 c}$ ) was prepared. Initial attempts to prepare the esters of organic acids was by acylation of tubercidin hydrochloride (2) using the procedure of Gish et al, ${ }^{8)}$ but the attempts failed. Subsequently success was achieved by treatment of $2^{\prime}, 3^{\prime}$-O-isopropylidenetubercidin (3) $)^{2}$ with chlorosulfonic acid or an acyl chloride or anhydride followed by mild hydrolysis to remove the isopropylidene group selectively (Scheme 1).

The structures of the five compounds isolated were established by method of preparation, analysis and spectral data all of which are reported in the Experimental. Somewhat surprisingly neither the hydrochloride 2 nor the $5^{\prime}$-O-sulfate $\mathbf{5 a}$ had ultraviolet spectra in water characteristic of tubercidin in strongly acidic solvents as these two compounds must be protonated even in neutral solutions.

Acetylation of tubercidin using acetic anhydride in pyridine gave the tri-O-acetyl derivative 6 when three moles of acetic anhydride per mole of tubercidin were employed. When a large excess of acetic anhydride was used, the product was the tri-O-acetyl-N-acetyl derivative 7

* Deceased December 14, 1970 
Scheme 1<smiles></smiles>

3

$\mathrm{X}=\mathrm{Cl}$ or $\mathrm{CH}_{3} \mathrm{COO}$

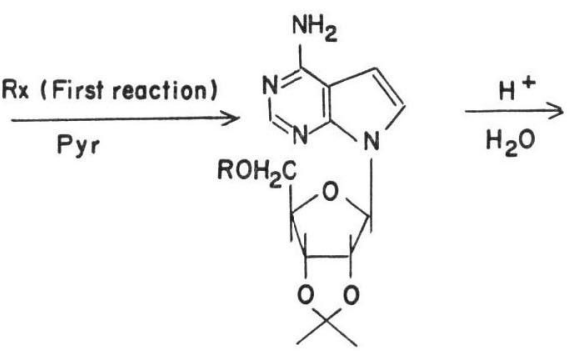

4 b $\quad \mathrm{R}=\mathrm{CH}_{3} \mathrm{CO}$

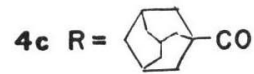<smiles>Nc1ncnc2c1ccn2C12CC3(O)OC1C(O)(O3)C2(O)O</smiles>

5a $\mathrm{R}=\mathrm{SO}_{3} \mathrm{H}$

5b $\mathrm{R}=\mathrm{CH}_{3} \mathrm{CO}$

5c $R=\leadsto-\mathrm{CO}$

Scheme 2<smiles>CC(=O)OCC1(OC(C)=O)C2OC(n3ccc4c(N)ncnc43)C1C2OC(C)=O</smiles>

6

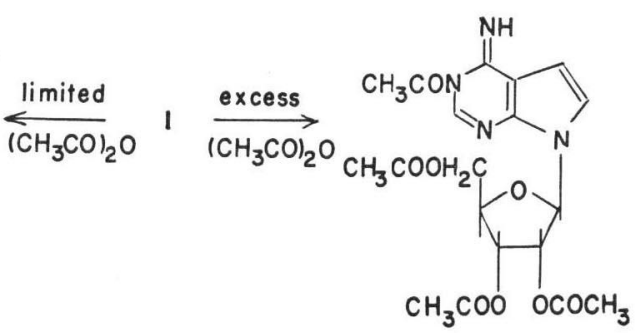

7

which has already been reported but not characterized ${ }^{9)}$ (Scheme 2). Neither 6 nor: 7 were crystalline and both were unstable at room temperature but stable at $-15^{\circ} \mathrm{C}$. The ${ }_{\mathrm{s}}^{\circ}$ structure of 6 is largely based on spectral data as the analysis gave values slightly outside the permitted limits. However, the high resolution mass spectrum conclusively established the proposed molecular formula. The only previously reported characterization of 7 was a KuHN-Roth acetyl determination indicating a tetraacetate. ${ }^{9)} \quad$ The analytical data and $\mathrm{nmr}$ spectrum derived from 7 quite conclusively demonstrate that it is a tetraacetyl compound and also indicate that three acetylgroups are attached to oxygen. Compound 7 shows maxima in its ultraviolet spectrum in neutral solution at 220 and $286 \mathrm{~nm}$. Gerster et al. ${ }^{5)}$ have shown that treatment of tubercidin with methyl iodide forms the $\mathrm{N}^{3}$-methyl hydroiodide. The compound thus prepared has two maxima $\left(228 \mathrm{~nm}\right.$ and $274 \mathrm{~nm}$ ) in its ultraviolet spectrum in neutral solution. ${ }^{3)}$ This is in contrast with tubercidin and tubercidin substituted by alkyl groups on $\mathrm{N}^{4}$ which have a single maximum in neutral or basic solutions and two maxima in strongly acidic solutions..$^{3,5)}$ Therefore the double maxima must indicate the presence of an imino form such as 7 which must then have an acetyl group at $\mathrm{N}^{3}$.

Benzoylation of tubercidin with an excess of benzoyl chloride under mild conditions resulted in a pentabenzoyl derivative 8 . Similar treatment of $2^{\prime}, 3^{\prime}$-O-isopropylidenetubercidin formed a tribenzoyl derivative 10 (Scheme 3). The number of benzoyl groups introduced was readily 
Scheme 3
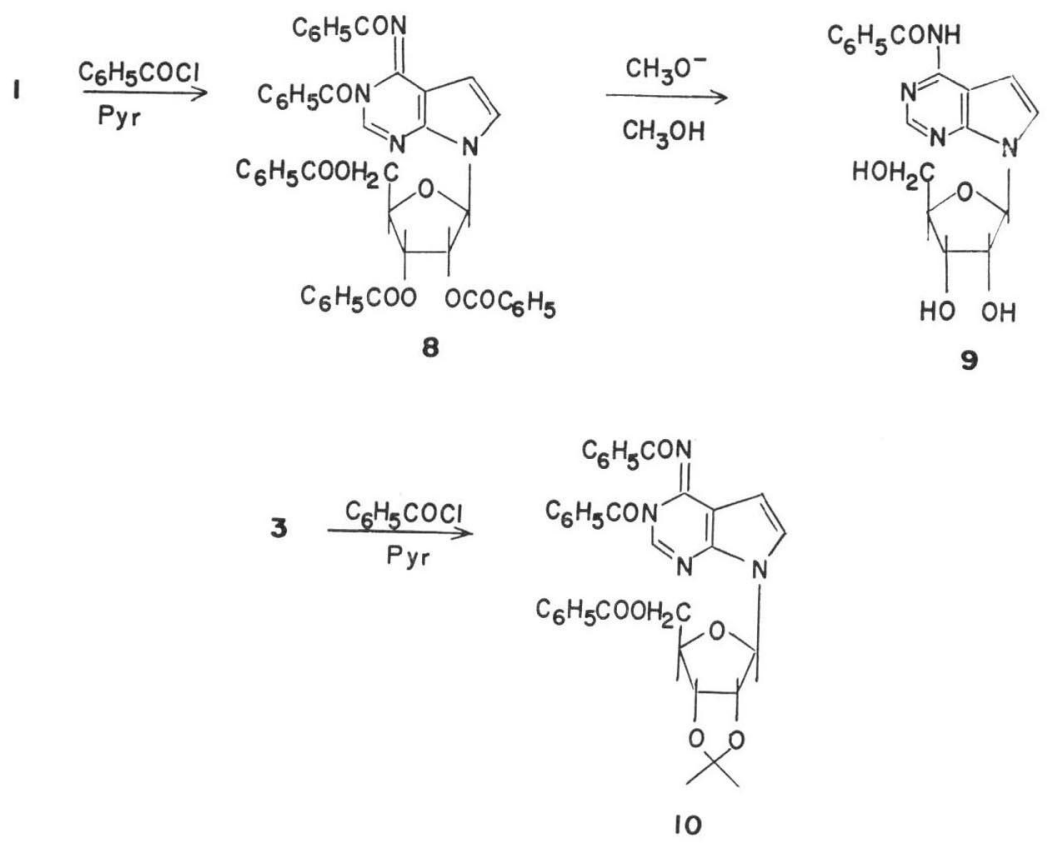

9

established by analysis, and in the case of $\mathbf{1 0}$ by its $\mathrm{nmr}$ spectrum. Treatment of $\mathbf{8}$ with sodium methoxide formed N-benzoyltubercidin (9). Since spectral and analytical data derived from $\mathbf{8}$ and $\mathbf{1 0}$ indicate clearly that they are, respectively, pentabenzoyl and tribenzoyl derivatives of tubercidin then two of the benzoyl groups in each case must be attached to the $7-$ deazaadenine portion of the molecule. The structures proposed were arrived at on the basis of analogy with the proposal of SMiтH et al. ${ }^{10)}$ that a tetrabenzoyladenosine prepared by them had benzoyl groups at $\mathrm{N}^{1}$ and $\mathrm{N}^{6}$, and the proposal of BentLey, CunNingham and Spring ${ }^{11}$ of a similar structure for tetrabenzoylcordycepin. It is not completely established that N-benzoyltubercidin has structure 9, but, again by analogy with the conversion of $\mathrm{N}^{3}$-methyltubercidin to 4-methylaminotubercidin, ${ }^{3,5}$ ) that structure seems more probable than does the alternative $\mathrm{N}^{3}$-benzoyl-4-imino structure analogous to 8 .

$\mathrm{N}^{4}$-Hydroxyethyltubercidin (11) ${ }^{4)}$ was prepared by the procedure of WINDMUELLeR and KAPLAN $^{12)}$ which involves treatment with ethylene oxide followed by base.

\section{Biological}

These compounds ( 2 through 11 with the exception of $\mathbf{8}$ and 9) were tested in vitro against L1210, a leukemia cell line. The results are given in Table 1 and are expressed as $\mu \mathrm{g} / \mathrm{ml}$ inhibiting growth of the cells by $50 \%$ and $90 \%$. As can be seen by comparison of 2 with the other compounds any sort of derivatization reduces activity in this assay although the monoacylates (5b and $\mathbf{5 c}$ ) are moderately active. Only compounds $\mathbf{5 b}, \mathbf{5 c}, \mathbf{6}$ and $\mathbf{7}$ were tested in vivo. The first two were tested against PS 388 in mice by i.p. administration. Compound $\mathbf{5 c}$ was inactive, but $\mathbf{5 b}$ had a $\mathrm{T} / \mathrm{C}$ of 1.52 when given at a dose of $1 \mathrm{mg} / \mathrm{kg}$. This is in the range of tubercidin itself. Compounds 6 and 7 were inactive against L1210 in mice and WALKeR carcinoma 256 in rats. Other biological data will be reported elsewhere. 
Table 1. Cytotoxicity.

\begin{tabular}{c|c|c}
\hline Compound & $\mathrm{ID}_{50}$ & $\mathrm{ID}_{80}$ \\
\cline { 1 - 2 } $\mathbf{2}$ & 0.0040 & 0.012 \\
$\mathbf{4 b}$ & $>10$ & $>10$ \\
$\mathbf{4 c}$ & $>10$ & $>10$ \\
$\mathbf{5 a}$ & 0.32 & 0.94 \\
$\mathbf{5 b}$ & 0.043 & 0.12 \\
$\mathbf{5 c}$ & 0.024 & 0.069 \\
$\mathbf{6}$ & 0.40 & 2.2 \\
$\mathbf{7}$ & 0.14 & 0.33 \\
$\mathbf{1 0}$ & $>10$ & $>10$ \\
$\mathbf{1 1}$ & 3.5 & $>10$ \\
\hline
\end{tabular}

\section{Experimental}

4-Amino-7- $\beta$-D-ribofuranosyl- $7 \mathrm{H}$ - pyrrolo [2,3-d]-pyrimidine hydrochloride (2)

One gram of tubercidin was dissolved in $4 \mathrm{ml}$ of $1 \mathrm{~N} \mathrm{HCl}$. The solution was refrigerated, filtered and the filter cake was washed with ethanol. Yield $0.73 \mathrm{~g}, \mathrm{mp} 250 \sim 252^{\circ} \mathrm{C}$ (dec.). Two recrystallizations from $85 \%$ and $80 \%$ ethanol successively caused no change in the mp: ir (Nujol) 3350 3120, 1685, 1650 (sh), 1520, 1505, 1460, 1380, 1350, 1330, 1240, $1125,1115,1080,1055,1035,1000,910,900$, 870,750 and $705 \mathrm{~cm}^{-1}$. UV $\left(\mathrm{H}_{2} \mathrm{O}, \mathrm{pH} 7\right) \max$ $270 \mathrm{~nm}(\varepsilon 10,950),\left(\mathrm{H}_{2} \mathrm{O}, \mathrm{pH} 2\right) \max 226 \mathrm{~nm}$ ( $\varepsilon 22,080)$ and $270 \mathrm{~nm}(\varepsilon 10,430)$; $\mathrm{nmr}\left(\mathrm{D}_{2} \mathrm{O}\right) \delta 3.78\left(\mathrm{~d}, 2, \mathrm{CH}_{2} \mathrm{O}\right), \delta 4.03 \sim 4.50$ (m, 3, CHO), $\delta 4.56$ (s, exch. H), $\delta 6.08(\mathrm{~d}, 1$, anomeric $\mathrm{H}), \delta 6.66(\mathrm{~d}, 1, \mathrm{CH}=), \delta 7.47(\mathrm{~d}, 1, \mathrm{NCH}=)$, $\delta 8.12(\mathrm{~s}, 1, \mathrm{NCH}=\mathrm{N})$.

Anal. Calcd. for $\mathrm{C}_{11} \mathrm{H}_{15} \mathrm{ClN}_{4} \mathrm{O}_{4}$ : C, 43.65; H, 5.00; N, $18.51 ; \mathrm{Cl}, 11.71$. Found: $\quad$ C, 43.49; H, 5.20; N, 18.33; Cl, 11.76 .

4-Amino-7-[ $\beta$-D-ribofuranosyl-5'-sulfate]-7H-pyrrolo-[2,3-d]-pyrimidine (5a)

A mixture of $2 \mathrm{~g}$ (6.5 mmoles) of $2^{\prime}, 3^{\prime}$-O-isopropylidenetubercidin and $20 \mathrm{ml}$ of dry pyridine was stirred at $-10^{\circ} \mathrm{C}$ while adding dropwise a solution of $1.51 \mathrm{~g}$ (13 mmoles) of $\mathrm{ClSO}_{3} \mathrm{H}$ in $6 \mathrm{ml}$ of dry $\mathrm{CHCl}_{3}$. The reaction mixture was allowed to warm slowly to room temperature followed by heating at $50^{\circ} \mathrm{C}$ for 15 minutes. The mixture was evaporated under reduced pressure to a syrup which was chromatographed on $100 \mathrm{ml}$ of Dowex $1 \times 8\left(\mathrm{HCOO}^{-}\right)$. The column was eluted with $500 \mathrm{ml}$ each of $0.01 \mathrm{~N}, 0.02 \mathrm{~N}$ and $0.04 \mathrm{~N} \mathrm{HCOOH}$ and $500 \mathrm{ml}$ each of $0.01 \mathrm{~N}, 0.02 \mathrm{~N}, 0.04 \mathrm{~N}, 0.1 \mathrm{~N}, 0.5 \mathrm{~N}$ and $1 \mathrm{~N} \mathrm{HCl}$ collecting 10-ml fractions. Fractions 309 368 were combined and concentrated to a volume of about $3 \mathrm{ml}$ under reduced pressure. Refrigeration of the residue followed by filtration and washing of the filter cake with ethanol gave $290 \mathrm{mg}$ of crystalline solid, $\mathrm{mp} 245^{\circ} \mathrm{C}$ (dec.). Two recrystallizations of $100 \mathrm{mg}$ from water gave a white solid, mp $265 \sim 267^{\circ} \mathrm{C}$ (dec.); ir (Nujol) 3310, $3120(\mathrm{NH} / \mathrm{OH}), 1660,1580,1530$, $1490,1445,1365,1255,1220,1205,1100,1055,995,950,900,865,815,790$ and $728 \mathrm{~cm}^{-1}$. $\mathrm{UV}\left(\mathrm{H}_{2} \mathrm{O}\right) \max 272 \mathrm{~nm}(\varepsilon 10,035), \mathrm{nmr}\left(\mathrm{D}_{2} \mathrm{O}\right) \delta 4.38\left(\mathrm{~s}, 2, \mathrm{CH}_{2} \mathrm{O}\right), \delta 4.3 \sim 4.70(\mathrm{~m}, 3, \mathrm{CHO})$, $\delta 4.73$ (s, exch. H), $\delta 6.22(\mathrm{~d}, 1$, anomeric $\mathrm{H}), \delta 6.57(\mathrm{~d}, 1, \mathrm{CH}=), \delta 7.42(\mathrm{~d}, \mathrm{NCH}=), \delta 8.05$ $(\mathrm{s}, 1, \mathrm{NCH}=\mathrm{N})$. $\mathrm{pKa}^{\prime}\left(\mathrm{H}_{2} \mathrm{O}\right) 5.2$.

Anal. Caled. for $\mathrm{C}_{11} \mathrm{H}_{14} \mathrm{~N}_{4} \mathrm{O}_{7} \mathrm{~S}$ : C, 38.16; H, 4.08; N, 16.18; S, 9.27; eq. wt. 346 . Found: $\quad$ C, 38.63; H, 4.17; N, 15.97; S, 9.47; eq. wt, 337.

4-Amino-7-[5'-O-acetyl-2', 3'-O-isopropylidene- $\beta$-D-ribofuranosyl]-7H-pyrrolo-[2,3-d]-pyrimidine $(\mathbf{4 b})$.

A solution of $5.35 \mathrm{~g}$ (17 mmoles) of $2^{\prime}, 3^{\prime}$-O-isopropylidenetubercidin in $65 \mathrm{ml}$ of dry pyridine was cooled in an ice-bath and stirred while a solution of $1.74 \mathrm{~g}(1.6 \mathrm{ml} ; 17 \mathrm{mmoles})$ of acetic anhydride was added dropwise. The reaction mixture was stirred at $0^{\circ} \mathrm{C}$ for 2 hours followed by stirring at room temperature overnight. The solution was poured into $750 \mathrm{ml}$ of water, and the aqueous mixture was extracted with four $400-\mathrm{ml}$ portions of chloroform. The combined extracts were dried $\left(\mathrm{MgSO}_{4}\right)$, filtered and concentrated under reduced pressure. The residue was dissolved in $30 \mathrm{ml}$ of chloroform and $250 \mathrm{ml}$ of Skellysolve B was added. The resulting ppt was purified further by two more precipitations in the same fashion. The final product was chromatographed on $250 \mathrm{~g}$ of silica gel using a solvent system consisting of ethyl acetate $-95 \%$ ethanol - water $(94: 4: 2)$ and collecting 5-ml fractions. Fractions 144 205 were combined and evaporated to dryness under reduced pressure. The residue was triturated with 
hexane and filtered. Yield $3.1 \mathrm{~g}, 58 \%, \mathrm{mp} 47 \sim 49^{\circ} \mathrm{C}$ : ir (Nujol) $3420(\mathrm{NH}), 1740$ (ester), 1620, $1580,1510,1465,1375,1210,1180,1150 \sim 1050 \mathrm{~cm}^{-1}$; $\mathrm{nmr}\left(\mathrm{CDCl}_{3}\right) \delta 1.42\left(\mathrm{~s}, 3, \mathrm{CH}_{3} \mathrm{C}\right), \delta 1.63$ (s, 3, $\left.\mathrm{CH}_{3} \mathrm{C}\right), \delta 2.04\left(\mathrm{~s}, 3, \mathrm{CH}_{3} \mathrm{CO}\right.$ ), $\delta 4.38$ (m, 3, CHO), $\delta 5.0 \sim 5.85\left(\mathrm{~m}, 4 \mathrm{H}, \mathrm{CHO}\right.$ and $\mathrm{NH}_{2}$ ), $\delta 6.24(\mathrm{~d}, 1$, anomeric $\mathrm{H}), \delta 6.42(\mathrm{~d}, 1, \mathrm{HC}=), \delta 7.08(\mathrm{~d}, 1, \mathrm{NHCH}=), \delta 8.35(\mathrm{~s}, 1, \mathrm{NCH}=\mathrm{N})$; mass spectrum $[m / e$, (relative intensity)] 348 (151), 217 (538), 163 (651), 135 (217), 134 (469), 107 (237), 69 (143), 55 (123), 43 (999).
Anal. Calcd. for $\mathrm{C}_{10} \mathrm{H}_{20} \mathrm{~N}_{4} \mathrm{O}_{5}$ :
C, $55.22 ; \mathrm{H}, 5.79 ; \mathrm{N}, 16.10$.
Found:
C, $55.10 ; \mathrm{H}, 5.93 ; \mathrm{N}, 15.97$.

4-Amino-7-[5'-O-acetyl- $\beta$-D-ribofuranosyl]-7H-pyrrolo-[2,3-d]-pyrimidine (5b).

A solution of $9.01 \mathrm{~g}$ (26 mmoles) of $5^{\prime}$-O-acetyl-2',3'-O-isopropylidenetubercidin in $90 \mathrm{ml}$ of trifluoroacetic acid was allowed to stand at room temperature for 10 minutes. The solvent was removed by evaporation under reduced pressure followed by repeated addition of methanol and reduced pressure evaporation. The residue was dissolved in $200 \mathrm{ml}$ of water, and the mixture was filtered. The filtrate was adjusted to $\mathrm{pH} 6.0$ with saturated $\mathrm{NaHCO}_{3}$ solution. After the mixture had been refrigerated, the crystals were collected, yield $3.85 \mathrm{~g}, 48 \%$. Recrystallization from methanol gave $2.48 \mathrm{~g}, \mathrm{mp} 198 \sim 200^{\circ} \mathrm{C}$ : ir (Nujol) $3400,3330,3180$ (NH/OH), 1745 (ester), 1640, 1595, 1560, 1510, 1485, 1340, 1320, 1275, 1250, 1225, 1130, 995 and $750 \mathrm{~cm}^{-1}$. UV (EtOH) $\max 269 \mathrm{~nm}(\varepsilon 11,710),(\mathrm{pH} 2) \max 227 \mathrm{~nm}(\varepsilon 23,240), 270 \mathrm{~nm}(\varepsilon$ 11,125); $\mathrm{nmr}\left(\mathrm{DMSO}-\mathrm{D}_{2} \mathrm{O}\right) \delta 2.05$ (s, 3, $\left.\mathrm{CH}_{3} \mathrm{CO}\right), \delta 4.0 \sim 4.6(\mathrm{~m}, 3 \mathrm{H}, \mathrm{CHO}), \delta 5.2 \sim 5.6(\mathrm{~m}, 2 \mathrm{H}$, $\mathrm{CHO}), \delta 6.08(\mathrm{~d}, 1$, anomeric $\mathrm{H}), \delta 6.6(\mathrm{~d}, 1, \mathrm{HC}=), \delta 7.3(\mathrm{~d}, 1, \mathrm{NCH}=), \delta 8.1(\mathrm{~s}, 1, \mathrm{NCH}=$ $\mathrm{N})$; mass spectrum $[\mathrm{m} / \mathrm{e}$ (relative intensity)] 308 (86), 177 (84), 163 (763), 147 (75), 135 (423), 134 (999), 107 (262), 43 (226); tlc $\left(\mathrm{CHCl}_{3}-\mathrm{MeOH}-\mathrm{H}_{2} \mathrm{O}\right.$; 78:20:2) Rf 0.37.

$\begin{array}{ll}\text { Anal. Calcd. for } \mathrm{C}_{13} \mathrm{H}_{18} \mathrm{~N}_{4} \mathrm{O}_{5}: & \text { C, } 50.69 ; \mathrm{H}, 5.24 ; \mathrm{N}, 18.19 . \\ \text { Found: } & \text { C, } 50.59 ; \mathrm{H}, 5.32 ; \mathrm{N}, 17.87 .\end{array}$

4-Amino-7-[5'-O-adamantane-1-carbonyl-2', 3'-O-isopropylidene- $\beta$-D-ribofuranosyl]-7H-pyrrolo[2,3-d]-pyrimidine $(\mathbf{4 c})$.

Eight and two-tenths grams (27 mmoles) of $2^{\prime}, 3^{\prime}$-O-isopropylidenetubercidin was dissolved in $125 \mathrm{ml}$ of dry pyridine. The solution was stirred while adding dropwise a solution of adamantane-1-carbonyl chloride [prepared from $5.2 \mathrm{~g}$ (29 mmoles) of adamantane-1-carboxylic acid and thionyl chloride] in $25 \mathrm{ml}$ of dry pyridine. After the reaction mixture had been stirred overnight at room temperature, it was heated under reflux for 3 hours. The pyridine was removed by evaporation at room temperature under reduced pressure. The residue was partitioned between $165 \mathrm{ml}$ of chloroform and $165 \mathrm{ml}$ of water. The water layer was removed and extracted with three $82-\mathrm{ml}$ portions of chloroform. The combined chloroform extracts were washed with $82 \mathrm{ml}$ of saturated $\mathrm{NaHCO}_{3}$ solution followed by washing with two 82-ml portions of water. The chloroform solution was dried $\left(\mathrm{MgSO}_{4}\right)$, filtered and concentrated under reduced pressure to a gummy solid, weight $12 \mathrm{~g}$. The crude product was chromatographed on $820 \mathrm{~g}$ of silica gel using the solvent system chloroform-methanol (95:5) and collecting 175 twenty-ml fractions. Fractions $128 \sim 163$ were combined and evaporated to dryness under reduced pressure leaving $9.2 \mathrm{~g}$ of residue which was dissolved in $55 \mathrm{ml}$ of methanol and treated with charcoal. Slow addition of $18 \mathrm{ml}$ of water to the hot filtrate followed by refrigeration gave $6.8 \mathrm{~g}(54 \%)$ of crystalline product, m.p. $155 \sim 158^{\circ} \mathrm{C}$. Repeated recrystallization from ethanol gave m.p. $163 \sim 165^{\circ}$ : ir (Nujol) 3505, 3365, 3245, 3135, 1695 (ester), 1660, 1610 and $1570 \mathrm{~cm}^{-1}$; UV (MeOH) $\max 268 \mathrm{~nm}(\varepsilon 12,450)$; $\mathrm{nmr}\left(\mathrm{CDCl}_{3}\right) \delta 1.41$ (s, 3, $\left.\mathrm{CH}_{3}\right), \delta 1.63$ (s, 3 , $\left.\mathrm{CH}_{3}\right), \delta 1.72 \sim 1.91\left(\mathrm{~m}, 15, \mathrm{CH}_{2}\right.$ and $\left.\mathrm{CH}\right), \delta 4.18(\mathrm{~m}, 3, \mathrm{CHO}), \delta 4.98(\mathrm{~m}, 1, \mathrm{CHO}), \delta 5.25 \sim 5.50$ $\left(\mathrm{m}, 3 \mathrm{H}, \mathrm{CHO}\right.$ and $\left.\mathrm{NH}_{2}\right), \delta 6.22(\mathrm{~d}, 1$, anomeric $\mathrm{H}), \delta 6.38(\mathrm{~d}, 1, \mathrm{CH}=), \delta 7.08(\mathrm{~d}, 1, \mathrm{NCH}=)$, $\delta 8.34(\mathrm{~s}, 1, \mathrm{NCH}=\mathrm{N})$.

Anal. Calcd. for $\mathrm{C}_{25} \mathrm{H}_{32} \mathrm{~N}_{4} \mathrm{O}_{5}$ : C, 64.08; H, 6.88; N, 11.96; mass spectrum 468.2393. Found:

C, $62.80 ; \mathrm{H}, 7.04 ; \mathrm{N}, 11.63 ;$ mass spectrum 468.2372 . 
4-Amino-7-[5'-O-adamantane-1-carbonyl- $\beta$-D-ribofuranosyl]-7H-pyrrolo-[2,3-d]-pyrimidine (5c).

A solution of $1 \mathrm{~g}$ of $5^{\prime}$-O-adamantane-1-carbonyl-2', $3^{\prime}$-O-isopropylidenetubercidin in $100 \mathrm{ml}$ of $0.1 \mathrm{~N} \mathrm{HCl}$ was boiled for 0.5 hour. The cooled reaction mixture was filtered through filter aid, and the filtrate was adjusted to $\mathrm{pH} 6$ with $1 \mathrm{~N} \mathrm{NaOH}$. After the aqueous mixture was refrigerated, the precipitate was removed by filtration to give $0.76 \mathrm{~g}$ of white solid. Two hundred $\mathrm{mg}$ of the product was chromatographed on $10 \mathrm{~g}$ of silica gel using the solvent system chloroform - methanol $(98: 2)$ until ninety-five 5-ml fractions had been collected. Elution was continued using the same solvent system in a ratio of 19:1 until a total of two hundred 5-ml fractions had been collected. Fractions $101 \sim 120$ were combined and evaporated to dryness under reduced pressure. The residue $(146 \mathrm{mg})$ was crystallized from a mixture of chloroform and methanol at $-15^{\circ} \mathrm{C}, \mathrm{mp} 235 \sim 237^{\circ} \mathrm{C}$, yield $78 \mathrm{mg}$ : ir (Nujol) 3390, $3290(\mathrm{NH} / \mathrm{OH}), 1710$ (ester), 1645, 1600, 1555, 1490, 1475, 1465, 1385, 1325, 1290, 1265, 1240, 1145, 1115, 1105, $1085,1070,1025,965,908,895,857,828,772,726$ and $702 \mathrm{~cm}^{-1}$; UV $(0.1 \mathrm{~N} \mathrm{HCl}) \max 226$ $\mathrm{nm}(\varepsilon 21,640), \max 270 \mathrm{~nm}(\varepsilon 10,700) ; \mathrm{nmr}\left(\mathrm{d}_{7} \mathrm{DMF}\right) \delta 1.7$ and 1.86 (d, 15, adamantanoyl), $\delta 4.1 \sim 4.7(\mathrm{~m}, 7, \mathrm{CHO}$ and $\mathrm{OH}), \delta 6.25(\mathrm{~d}, 1$, anomeric $\mathrm{H}), \delta 6.72(\mathrm{~d}, 1, \mathrm{CH}=), \delta 6.96(\mathrm{~s}, 2$, $\left.\mathrm{NH}_{2}\right), \delta 7.32(\mathrm{~d}, 1, \mathrm{NCH}=), \delta 8.13(\mathrm{~s}, 1, \mathrm{~N}=\mathrm{CHN})$.

Anal. Caled. for $\mathrm{C}_{22} \mathrm{H}_{28} \mathrm{~N}_{4} \mathrm{O}_{5}$ : C, 61.67; H, 6.59; N, 13.08 . Found: C, $61.44 ; \mathrm{H}, 6.59 ; \mathrm{N}, 13.62$.

4-Amino-7-[2', 3', 5'-tri-O-acetyl- $\beta$-D-ribofuranosyl]-7H-pyrrolo-[2,3-d]-pyrimidine (6).

A mixture of $2 \mathrm{~g}(7.5 \mathrm{mmoles})$ of tubercidin and $14 \mathrm{ml}$ of dry pyridine was cooled in an ice-bath and stirred while adding dropwise a solution of $2.6 \mathrm{~g}(2.4 \mathrm{ml}, 26$ mmoles $)$ of acetic anhydride in $7 \mathrm{ml}$ of dry pyridine. The mixture was cooled and stirred an additional 2 hours and finally stirred overnight at room temperature. As stirring proceeded the solid present gradually dissolved. The reaction mixture was poured into $200 \mathrm{ml}$ of water, and the resulting mixture was extracted with four $50-\mathrm{ml}$ portions of chloroform. The combined extracts were dried $\left(\mathrm{MgSO}_{4}\right)$, filtered and concentrated under reduced pressure finally keeping at $0.5 \mathrm{~mm}$ for 16 hours. The residue was dissolved in $10 \mathrm{ml}$ of chloroform and $75 \mathrm{ml}$ of Skellysolve B was added. After the supernatant had become clear, it was decanted, and the residual solvent was removed by evaporation under reduced pressure $(0.5 \mathrm{~mm})$. The solution and precipitation procedure was repeated, yield $2.3 \mathrm{~g}$.

One gram was chromatographed on $50 \mathrm{~g}$ of silica gel using chloroform-methanol $(98: 2)$ and collecting two hundred and fifty 5-ml fractions. Fractions $80 \sim 105$ were combined and evaporated to dryness under reduced pressure, yield $486 \mathrm{mg}, \mathrm{mp} 56 \sim 80^{\circ} \mathrm{C}$; tlc (silica gel; cyclohexane - ethyl acetate-95\% ethanol; 5:3:2) Rf 0.25; ir (Nujol) 3440, 3340, 3160, 1740, $1635,1585,1560,1510,1235,1095$ and $1040 \mathrm{~cm}^{-1}$; UV (EtOH) $\max 268 \mathrm{~nm}(\varepsilon 11,150)$; nmr $\left(\mathrm{CDCl}_{3}\right) \delta 2.03\left(\mathrm{~s}, 3, \mathrm{CH}_{3} \mathrm{CO}\right), \delta 2.13\left(\mathrm{~s}, 6, \mathrm{CH}_{3} \mathrm{CO}\right), \delta 4.39\left(\mathrm{~d}, 2, \mathrm{CH}_{2} \mathrm{O}\right), \delta 5.3 \sim 5.9(\mathrm{~m}, 3$, $\mathrm{CHO}), \delta 6.45(\mathrm{~m}, 2$, anomeric and $\mathrm{CH}=), \delta 7.12(\mathrm{~d}, 1, \mathrm{NCH}=), \delta 8.34(\mathrm{~s}, 1, \mathrm{~N}=\mathrm{CHN})$.

Anal. Calcd. for $\mathrm{C}_{17} \mathrm{H}_{20} \mathrm{~N}_{4} \mathrm{O}_{7}$ : C, 52.04; H, 5.14; N, 14.28; mass spectrum 392.1332.

Found: $\quad$ C, $51.40 ; \mathrm{H}, 5.21$; N, 13.48; mass spectrum 392.1345.

4-Imino-3-acetyl-7-[2', 3', 5'-tri-O-acetyl- $\beta$-D-ribofuranosyl]-7H-pyrrolo[2,3-d]-pyrimidine (7).

A mixture of $1 \mathrm{~g}$ of tubercidin, $10 \mathrm{ml}$ of acetic anhydride and $30 \mathrm{ml}$ of dry pyridine was stirred at room temperature until the solid had dissolved and was then allowed to stand for 2 days. The solution was poured into $400 \mathrm{ml}$ of water, and the mixture was extracted with five $50-\mathrm{ml}$ portions of chloroform. The combined extracts were dried $\left(\mathrm{MgSO}_{4}\right)$, the mixture was filtered and the filtrate was evaporated to dryness under reduced pressure at $35^{\circ} \mathrm{C}$. The residual gum was chromatographed on $50 \mathrm{~g}$ of silica gel using chloroform as the eluent until one hundred and thirty $5-\mathrm{ml}$ fractions had been collected. Elution was continued with a 98:2 mixture of chloroform-methanol until a total of 200 fractions had been collected. Fractions 148 189 were combined and concentrated under reduced pressure to give $1.31 \mathrm{~g}$ of a gummy, colorless residue. Solution of the residue in $5 \mathrm{ml}$ of chloroform and precipitation with Skellysolve B gave $0.90 \mathrm{~g}$ of amorphous solid, $\mathrm{mp} 60 \sim 80^{\circ} \mathrm{C}$ : ir (Nujol) 3200 (NH), 1730 (ester), 
1680 (sh, amide), 1590, 1550,1490,1445, 1360, 1295, 1230, 1090, 1040, 890 and $740 \mathrm{~cm}^{-1}$; UV (EtOH) $\max 220 \mathrm{~nm}(\varepsilon 28,850)$, sh $230 \mathrm{~nm}(\varepsilon 13,900)$, $\max 286 \mathrm{~nm}(\varepsilon 7,600)$, (EtOH, HCl) $\max$ $242 \mathrm{~nm}(\varepsilon 38,500)$, $\max 287 \mathrm{~nm}(\varepsilon 11,525) ; \mathrm{nmr}\left(\mathrm{CDCl}_{3}\right) \delta 2.05$ (s, 3, $\left.\mathrm{CH}_{3} \mathrm{COO}\right), \delta 2.15$ (s, 6, $\mathrm{CH}_{3} \mathrm{COO}$ ), $\delta 2.37$ (s, 3, $\left.\mathrm{CH}_{3} \mathrm{CON}\right), \delta 4.42$ (m, 3, CHO), $\delta 5.55 \sim 5.90$ (m, 2, CHO), $\delta 6.53$ (d, 1 , anomeric $\mathrm{H}), \delta 7.08(\mathrm{~d}, 1, \mathrm{CH}=), \delta 7.32(\mathrm{~d}, 1, \mathrm{NCH}=), \delta 8.57(\mathrm{~s}, 1, \mathrm{NCH}=\mathrm{N})$.

Anal. Calcd. for $\mathrm{C}_{18} \mathrm{H}_{22} \mathrm{~N}_{4} \mathrm{O}_{3}$ : C, 52.53; H, 5.11; N, 12.90 . Found:

C, $52.27 ; \mathrm{H}, 5.36 ; \mathrm{N}, 13.17$.

4-Benzamido-7-( $\beta$-D-ribofuranosyl)-pyrrolo-[2,3-d]-pyrimidine (9).

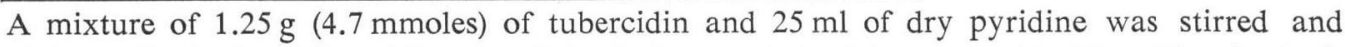
cooled in an ice-bath while adding $3 \mathrm{~g}(3.8 \mathrm{ml} ; 21 \mathrm{mmoles})$ of benzoyl chloride. The ice-bath was removed, and the reaction mixture was stirred at room temperature for 40 hours. The mixture was poured with constant stirring into a mixture of ice and water, and stirring was continued until the precipitate was crystalline. The solid was removed by filtration and recrystallized twice by dissolving in hot acetone and adding about $10 \%$ water, yield $2.37 \mathrm{~g}(64 \%)$, m.p. $187 \sim 188^{\circ} \mathrm{C}$, tlc (silica gel; ethyl acetate-cyclohexane, $1: 1$ ) Rf 0.61 .

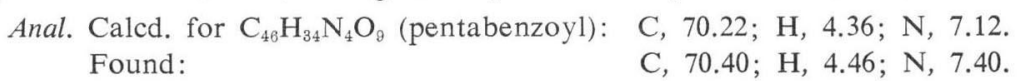

One-half gram $(0.63 \mathrm{mmole})$ of the above product in a mixture of $25 \mathrm{ml}$ of absolute methanol and $25 \mathrm{ml}$ of anhydrous tetrahydrofuran was cooled in an ice-bath and $0.5 \mathrm{ml}$ of $25 \%$ methanolic sodium methoxide solution was added. After the reaction had proceeded for eight hours, the reaction mixture was neutralized with an excess of Dowex $50 \times 8$ (pyridinium form). The mixture was filtered, and the filtrate was concentrated to a syrup under reduced pressure. The residue was crystallized twice from isopropanol and once from a 1:1 mixture of methanol-isopropanol, yield $65 \mathrm{mg}\left(29 \%\right.$ ), m.p. $181 \sim 182^{\circ} \mathrm{C}$ : ir (Nujol) $3560,3300,3260$, 1680 (amide), 1605, 1565, 1515, 1510, 1490, 1255, 1120, 1115, 1050, 1030, 735 and $720 \mathrm{~cm}^{-1}$; UV (EtOH) max $225 \mathrm{~nm}(\varepsilon 27,100)$, sh $238 \mathrm{~nm}(\varepsilon 22,950)$, $\max 305 \mathrm{~nm}(\varepsilon$ 9,200).

Anal. Calcd. for $\mathrm{C}_{18} \mathrm{H}_{18} \mathrm{~N}_{4} \mathrm{O}_{5}$ : C, 58.37; H, 4.90; N, 15.13 . Found: $\quad$ C, $58.42 ; \mathrm{H}, 4.96 ; \mathrm{N}, 14.96$.

3-Benzoyl-4-benzimido-7-[5'-O-benzoyl-2', 3'-O-isopropylidene- $\beta$ - D - ribofuranosyl] - 7H - pyrrolo [2,3-d]-pyrimidine (10).

A solution of $1.74 \mathrm{~g}$ (6 mmoles) of $2^{\prime}, 3^{\prime}$-O-isopropylidenetubercidin in $50 \mathrm{ml}$ of dry pyridine was stirred in an ice-bath and $4.35 \mathrm{ml}(5.35 \mathrm{~g} ; 37$ mmoles $)$ of benzoyl chloride was added. After the reaction mixture had stood for $1 \frac{1}{2}$ hours, the solution was poured into a mixture of ice and water which was then made slightly acidic by addition of $2 \mathrm{~N} \mathrm{HCl}$. The resulting precipitate was removed by filtration. The product was recrystallized from acetone-water to give $3.28 \mathrm{~g}$, m.p. $178 \sim 180^{\circ} \mathrm{C}$, in two crops, yield $89 \%$. Recrystallization from the same solvent gave $2.4 \mathrm{~g}$, m.p. $181.5 \sim 183^{\circ} \mathrm{C}$ : ir (Nujol) 1718 (ester), 1690 (amide), 1585, 1575, 1543, $1440,1362,1255,1245,1070,850,715$ and $690 \mathrm{~cm}^{-1}$; UV (EtOH) $\max 225 \mathrm{~nm}(\varepsilon$ 36,640), sh 275 ( 1 10,500); $\mathrm{nmr}\left(\mathrm{CDCl}_{3}\right) \delta 1.44\left(\mathrm{~s}, 3, \mathrm{CH}_{3}\right), \delta 2.0\left(\mathrm{~s}, 3, \mathrm{CH}_{3}\right), \delta 4.75(\mathrm{~s}, 3, \mathrm{CHO}), \delta 5.0 \sim 5.5$ $(\mathrm{m}, 2, \mathrm{CHO}), \delta 6.35(\mathrm{~m}, 2$, anomeric and $\mathrm{CH}=), \delta 7.15 \sim 8.2(\mathrm{~m}, 16 \mathrm{H}$, aromatic and $\mathrm{NCH}=)$, $\delta 8.75(\mathrm{~s}, 1, \mathrm{NCH}=\mathrm{N})$.

Anal. Calcd. for $\mathrm{C}_{35} \mathrm{H}_{30} \mathrm{~N}_{4} \mathrm{O}_{7}$ : C, 67.93; H, 4.89; N, 9.06; mass spectrum 618.2114. Found: $\quad$ C, 67.31; H, 5.04; N, 9.13; mass spectrum 618.2108.

4-(2-Hydroxyethyl) amino-7- $\beta$-D-ribofuranosyl-7H-pyrrolo-[2,3-d]-pyrimidine (11).

A mixture of $1 \mathrm{~g}$ of tubercidin and $15 \mathrm{ml}$ of water saturated with ethylene oxide was stirred while ethylene oxide was bubbled through for five days. The solution was maintained at $\mathrm{pH} 6.5$ by occasional addition of $1 \%$ perchloric acid. After the reaction was complete the $\mathrm{pH}$ was lowered to 5.0 with perchloric acid, and the mixture was filtered. The filtrate was evaporated to dryness under reduced pressure. The residue was dissolved in $40 \mathrm{ml}$ of water, and $1 \mathrm{~N} \mathrm{NaOH}$ was added until the $\mathrm{pH}$ was 11.0 . The mixture was kept at $60^{\circ} \mathrm{C}$ for 24 hours 
followed by concentration to dryness under reduced pressure. The residue was triturated with water, refrigerated and filtered with thorough washing. The product was recrystallized by dissolving it in acid and making the solution basic, yield $0.25 \mathrm{~g}$. Repeated recrystallization gave a $\mathrm{mp}$ of $210 \sim 210.5^{\circ} \mathrm{C}$; ir (Nujol) $3370,3320,3180,1620,1565,1530$ and $1505 \mathrm{~cm}^{-1}$; UV $\left(0.01 \mathrm{~N} \mathrm{H}_{2} \mathrm{SO}_{4}\right) \max 230 \mathrm{~nm}(\varepsilon 22,940), \max 274 \mathrm{~nm}(\varepsilon 17,670) ; \mathrm{nmr}\left(\mathrm{d}_{7} \mathrm{DMF}\right) \delta 3.78(\mathrm{~m}, 4$, $\left.\mathrm{OCH}_{2} \mathrm{CH}_{2} \mathrm{~N}\right), \delta 4.10 \sim 4.70(\mathrm{~m}, 5, \mathrm{CHO}), \delta 6.11(\mathrm{~d}, 1$, anomeric $\mathrm{H}), \delta 6.70(\mathrm{~d}, 1, \mathrm{CH}=), \delta 7.40$ $(\mathrm{d}, 1, \mathrm{NCH}=), \delta 8.18(\mathrm{~s}, 1, \mathrm{NCH}=\mathrm{N})$.

Anal. Calcd. for $\mathrm{C}_{13} \mathrm{H}_{18} \mathrm{~N}_{4} \mathrm{O}_{5}$ : C, 50.31; H, 5.84; N, 18.06 .

Found:

C, $50.13 ; \mathrm{H}, 5.83 ; \mathrm{N}, 18.11$.

\section{Acknowledgment}

The authors wish to thank Mr. Nelson J. Major and Mr. Alfred Koning for technical assistance and also thank members of the Physical and Analytical Chemistry Department of The Upjohn Company for analytical and spectral data.

This work was supported in part by Contract NO1-CM-43753 and previous contracts from the Division of Cancer Treatment, National Cancer Institute, National Institutes of Health, Department of Health, Education, and Welfare.

\section{References}

1) Anzai, K.; G. Nakamura \& S. Suzuki: A new antibiotic, tubercidin. J. Antibiotics, Ser. A 10: 201 204, 1957

2) Pike, J.E.; L. Slechta \& P.F. Wiley: Tubercidin and related compounds. J. Heterocycl. Chem. 1: 159 161, 1964

3) WILEY, P.F.: Process for the production of $\mathrm{N}^{6}$-methyltubercidin and intermediate. U.S. Pat. 3,364,198, Jan. 16, 1968

4) Wiley, P.F.: 4-(2-Hydroxyethyl) tubercidin. Neth. Pat. Appl. 6,513,129, Apr. 13, 1966

5) Gerster, J.F.; B. Carpenter, R.K. Robins \& L.B. Townsend: Pyrrolopyrimidine nucleosides. I. The synthesis of 4-substituted 7-( $\beta$-D-ribofuranosyl) pyrrolo [2,3-d] pyrimidines from tubercidin. J. Med. Chem. 10: 326 331, 1967

6) Fleysher, M.H.; A. Bloch, M.T. Hakala \& C.A. Nichol: Synthesis and biological activity of some new $\mathrm{N}^{6}$-substituted purine nucleosides. J. Med. Chem. 12: 1056 1061, 1969

7) Anzai, K. \& M. Matsui: 8,5'-O-Cyclonucleosides of tubercidin. Bull. Chem. Soc. Japan 47: 417 420, 1974

8) Gish, D.T.; R.C. Kelly, G.W. Camiener \& W.J. Wechter: Nucleic acids. 11. Synthesis of $5^{\prime}$-esters of $1-\beta$-D-arabinofuranosylcytosine possessing antileukemic and immunosuppressive activity.

J. Med. Chem. 14: 1159 1162, 1971

9) Suzuki, S. \& S. Marumo: Chemical structure of tubercidin. J. Antibiotics, Ser. A 14: 34 38, 1961

10) Smith, M.; D.H. Rammler, I.H. Goldberg \& H.G. Khorana: Studies on polynucleotides. XIV. Specific synthesis of $\mathrm{C}_{3}{ }^{\prime}-\mathrm{C}_{5}{ }^{\prime}$ internucleotide linkage. Syntheses of uridylyl-(3'-5')-uridine and uridylyl- $\left(3^{\prime}-5^{\prime}\right)$ adenosine. J. Amer. Chem. Soc. 84: 430 440, 1962

11) Bentley, H.R.; K.G. Cunningham \& F.S. Spring: Cordycepin. A metabolic product of Cordyceps militaris (LinN.) Link. II. The structure of cordycepin. J. Chem. Soc. 1951: 2301 2305, 1951

12) Windmueller, H.G. \& N.A. Kaplan: The preparation and properties of N-hydroxyethyl derivatives of adenosine, adenosine triphosphate, and nicotinamide adenine dinucleotide. J. Biol. Chem. 236: 2716 2726, 1961 